\title{
Toxic Thyroid Nodule with Activating Point Mutation in Gene Encoding the $\alpha$ Subunit of the Stimulatory G Protein: Case Report
}

\author{
Machiko Endo, Atsushi Nagumo, Yasunori Hirose, Toshihiro Tajima and Kenji Fujieda \\ Department of Pediatrics, Hakodate Chuo Hospital, (ME, AN), Hakodate Goryokaku Hospital, (ME), Hokkaido, \\ Fukuoka Children's Hospital, (AN), Fukuoka, Department of Surgery, Hakodate Chuo Hospital, (YH), Department \\ of Pediatrics, Hokkaido University School of Medicine, (TT, KF), Hokkaido, Japan
}

\begin{abstract}
We report the identification of a somatic mutation in the gene encoding the $\alpha$ subunit of the stimulatory G protein (Gs $\alpha$ ) of adenylyl cyclase in an 8-year-old girl with a toxic thyroid nodule. She had symptoms and signs of thyrotoxicosis. The nodule was resected and found to be an adenoma. To clarify the molecular basis of this tumor, the presence of mutations at codon 201 and 227 in the Gs $\alpha$ gene was sought in deoxyribonucleic acid (DNA) extracted from the tumor and the patient's blood using polymerase chain reaction amplification (PCR). A G-to-A transition resulting in the replacement of Arg by His (Arg 201 to His) was found in exon 8 of one allele encoding Gs $\alpha$. Because thyrocytes are programmed to proliferate in response to elevated 3',5'-cyclic AMP (cAMP) levels, the activating Gs $\alpha$ mutation observed in this patient probably contributed to tumorgenic development. To our knowledge, this is the first case in which the activating Gs $\alpha$ mutation in a Japanese child with a toxic thyroid adenoma has been identified.
\end{abstract}

Key words: stimulatory $\mathrm{G}$ protein gene, somatic mutation, toxic thyroid nodule

\section{Introduction}

Recent studies have demonstrated that mutations in the gene encoding the $\alpha$ subunit of Gs $\alpha$ can cause diseases, such as GH-secreting pituitary tumors, autonomously functioning thyroid tumors and the McCune-Albright syndrome (1-9). These somatic mutations cause

Received: July 27, 1994

Accepted: April 27, 1995

Correspondence: Dr. Kenji Fujieda, Department of Pediatrics, Hokkaido

Univesity School of Medicine, Kita 15-jyo Nishi 7-chome, Kita-ku

Sapporo-shi, Hokkaido 060 Japan amino acid replacement of Arg 201 by Cys or His in exon 8 and of Gln 227 by Arg or His. In vitro studies have shown that these abnormal Gs $\alpha$ proteins have markedly reduced guanosine triphosphatase (GTPase) activity and are able to stimulate adenylyl cyclase $(1,7,10)$. Concerning thyroid tumors, according to two studies, Gs $\alpha$ mutations were found in autonomously functioning adenomas $(3,4,8,9)$. Gs $\alpha$ mutations were also identified in three carcinomas (4).

We describe the case of an 8-year-old girl with a toxic thyroid adenoma in whom the activating Gs $\alpha$ mutation from the tumor was 


\section{Endo et al.}

identified.

\section{Case report}

An eight year old girl developed a left cervical mass and was referred to our hospital with weight loss, hyperphagia, restlessness and excessive perspiration. Physical examination disclosed a slim and wasted girl (weight $29 \mathrm{~kg}$; height $144 \mathrm{~cm}$ ) with no exophthalmos. Blood pressure was 134/60 mmHg and pulse rate 104 beats $/ \mathrm{min}$. The thyroid gland was enlarged $(78 \times$ $40 \mathrm{~mm}$ ) and at the upper part of the left lobe a $25 \times 25 \mathrm{~mm}$ oval hard mass was palpable. Hematologic and biochemical results were within the normal ranges. Endocrinological examination results are listed in Tables 1 and 2 . Serum values for thyroxine $\left(\mathrm{T}_{4}\right)(22.8 \mu \mathrm{g} / \mathrm{dL})$, free $\mathrm{T}_{4}(4.42 \mu \mathrm{g} / \mathrm{dL}), 3,5,3$ '-triiodothyronine ( $\left.\mathrm{T}_{3}\right)(775 \mathrm{ng} / \mathrm{dL})$, free $\mathrm{T}_{3}(>15 \mathrm{pg} / \mathrm{mL})$ were elevated. The basal thyrotropin concentration was $<0.02 \mu \mathrm{U} / \mathrm{mL}$ and did not increase after administration of TRH. Antibodies to thyroglobulin and thyroid microsome antigen were not

Table 1 Thyroid function of patient

\begin{tabular}{llllll}
\hline T3 & $(\mathrm{ng} / \mathrm{dl})$ & 775 & TRAb & $(\%)$ & 2.6 \\
free T3 & $(\mathrm{pg} / \mathrm{ml})$ & $>15$ & TGAb & $(\%)$ & 5.2 \\
$T_{4}$ & $(\mu \mathrm{g} / \mathrm{dl})$ & 22.8 & TBG & $(\mu \mathrm{g} / \mathrm{ml})$ & 20 \\
free $\mathrm{T}_{4}$ & $(\mu \mathrm{g} / \mathrm{dl})$ & 4.42 & TSAB & $(\mu / \mathrm{ml})$ & $<0.3$ \\
TSH & $(\mu \mathrm{U} / \mathrm{ml})$ & $<0.02$ & TSBAB & $(\%)$ & 3.5 \\
\hline
\end{tabular}

Table $2{ }^{123}$ I uptake and suppression test

\begin{tabular}{lcc}
\hline & pre suppression & post suppression \\
\hline $3 \mathrm{hr}$ & $6.48 \%$ & $6.82 \%$ \\
$24 \mathrm{hr}$ & $23.37 \%$ & $20.43 \%$ \\
\hline
\end{tabular}
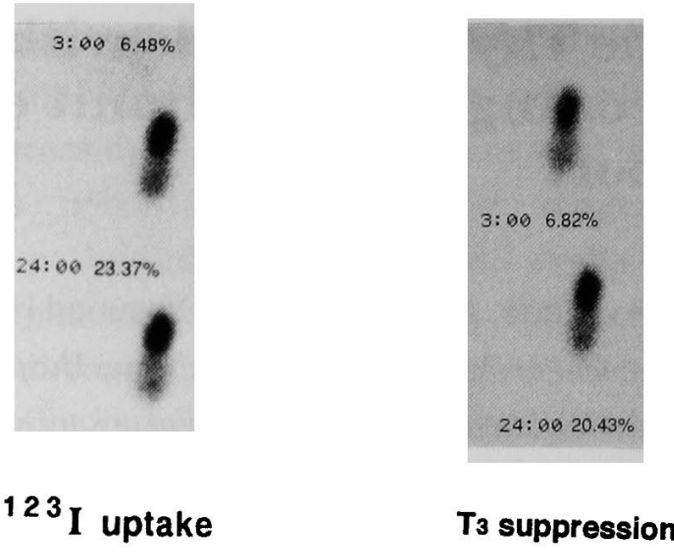

Fig. $1{ }^{123} \mathrm{I}$ uptake and T3 suppression test. ${ }^{123} \mathrm{I}$ uptake after seven days treatment with $\mathrm{T}_{3}(75 \mu \mathrm{g} /$ day) was not suppressed.

detected. Technetium was concentrated mainly within the intrathyroidal mass. ${ }^{123} \mathrm{I}$ uptake after seven days treatment with $\mathrm{T}_{3}$ ( $75 \mu \mathrm{g} /$ day) was not suppressed (20.43\%)(Table 2, Fig. 1). On the basis of these findings she was diagnosed as suffering from a toxic thyroid nodule and a left hemithyroidectomy was performed. Histological examination revealed a follicular adenoma with much colloid and many vacuolations (Fig. 2).

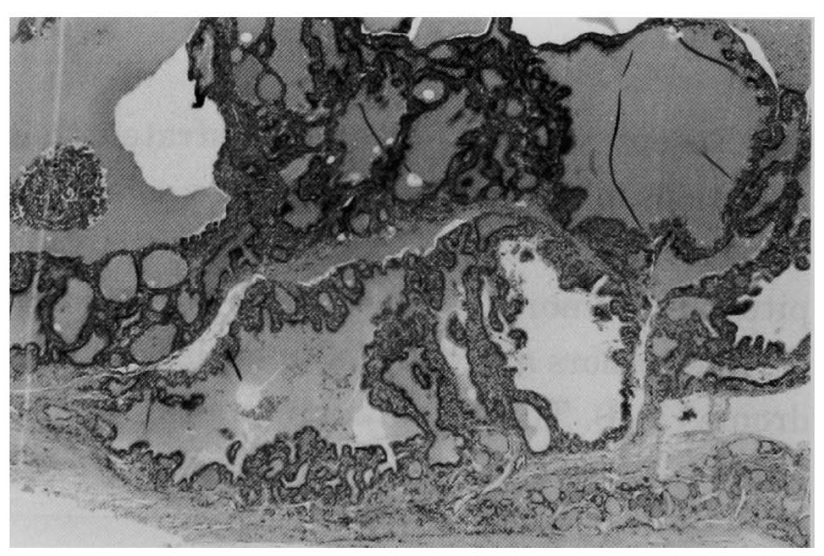

Fig. 2 Histological findings of the resected nodule. There is much colloid and many vacuolations in the follicullar cells and no atypical cells. 


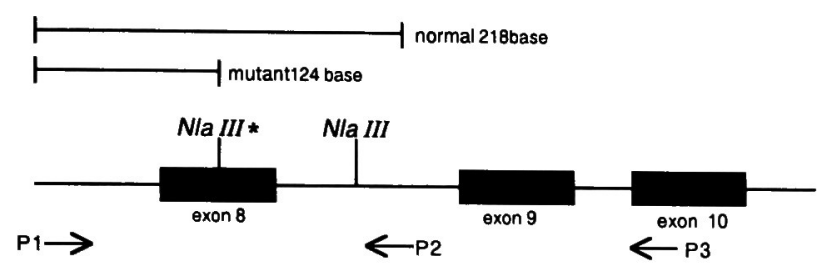

P1: 5'-CTCTGAGCCCTCTITCCAAACTAC-3' P2: 5'-GGTTATTCCAGAGGGACTGGGGTGAA-3' P3: 5'-GCTGCTGGCCACCACGAAGATGAT-3'

Fig. 3A Schematic representation of exon 8 and exon 9 of Gs $\alpha$ gene. Three primers, P1, P2 and P3 were used for PCR amplification $(1,6)$. Amplification was accomplished in 35 cycles of $1 \mathrm{~min}$ at $94^{\circ} \mathrm{C}, 2 \mathrm{~min}$ at $55^{\circ} \mathrm{C}$ and $3 \mathrm{~min}$ at $72^{\circ} \mathrm{C}(1,6)$. Nlalll shows the position of restriction sites in the PCR fragment. The Arg 201 to His missense mutation introduces a NlaIII restriction site into DNA fragment. The lines indicate the predicted sizes of PCR-fragments after digestion with NlaIII for the normal and mutant alleles.
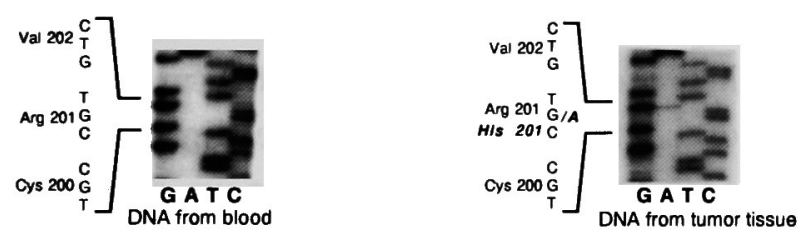

Fig. 3B DNA sequence analysis. To sequence exon 8 and exon 9 directly, the PCR was conducted using primers pair of P1-P3 as described previousiy $(1,6)$. The PCR product was sequenced directly as double stranded DNA with Sequenase (U.S.Biochemicals)(11). Note the G-to-A transition in the codon 201 Arg of DNA from tumor tissue, not from blood DNA. The mutant allele encodes His at this position. Note also the presence of an NlaIII restriction endonuclease site (CATG) in the only mutant allele.

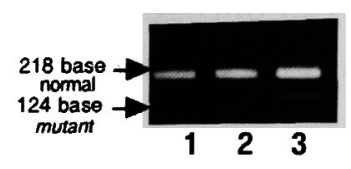

Fig. 3C $3 \%$ agarose gel electrophoresis of the PCR fragments produced by primers pair P1-P2 (6) after digestion with NlaIII. Lane 1: normal control, Lane 2: DNA from the patient's blood, Lane 3: DNA from tumor tissue. The presence of normal (218 base) and mutant (124 base) bands from tumor tissue confirmed the mutation in the codon $201 \mathrm{Arg}$, and this mutation was somatic in origin.
Two months after the operation, she was in a euthyroid state.

To elucidate the molecular basis of this tumor, we amplified DNA fragments encompassing the sites of known activating missense mutations of Gs $\alpha$ (Arg 201 in exon 8 and Gln 227 in exon 9) from tumor tissue and whole blood from this patient by the polymerase chain reaction using appropriate primers as described previously (Fig. 3A) $(1,6)$ and searched for mutations using direct sequence and restriction endonuclease digestion (6, 11)(Fig. 3A). By direct sequence, DNA from tumor tissue revealed a G-to-A transition resulting in the replacement of Arg 201 by His in exon 8 (Fig. 3B), while this mutation was not found in blood genomic DNA. This suggests that the mutation in the thyroid tumor was somatic in origin by analogy with most dominant oncogenes. The Arg 201 to His missense mutation introduces an NlaII restriction endonuclease site into the DNA (6). As shown in Fig. 3C, exon 8 fragment amplified from tumor tissue produces two fragments (lane $3)$. In contrast, whole blood DNA and control DNA are cut at a single NlaII sites. These results confirm the presence of the mutation in the PCR fragment amplified from thyroid tumor tissue.

\section{Discussion}

In this 8-year-old girl with a toxic thyroid adenoma the activating mutation (Arg 201 to His) of Gs $\alpha$ mutation was identified from tumor tissue. Recent molecular work has indicated several possible pathogenic mechanisms for autonomously functioning thyroid tumors (1, 3, $4,8,9$ ). In our case, we speculate that an activating Gs $\alpha$ mutation was the likely cause of 
tumor development for the following reasons: First, in vitro mutagenesis studies demonstrate that replacement of Arg by Cys or His reduces the GTPase activity of Gs $\alpha$ by approximately 30 -fold and enhances the ability of Gs $\alpha$ to stimulate adenylyl cyclase $(1,7)$. Moreover, expression of the Arg 201 to His of Gs $\alpha$ protein in Gs $\alpha$ deficient S49 cyc-murine lymphoma cells reproduces the adenylyl cyclase phenotype observed in the GH-secreting tumors containing the mutant $\mathrm{Gs}_{\mathrm{s}}(7,10)$. In addition, the cholera toxin gene has been placed under the control of the GH promoter in a transgenic mouse model. These mice displayed somatotroph proliferation, pituitary hyperplasia, elevated GH, and gigantism, indicating that alternation of Arg 201 to His in Gs $\alpha$ is sufficient to activate adenylyl cyclase and cause autonomous $\mathrm{GH}$ secretion and cellular proliferation $(7,10)$. Also, by molecular analysis of Gs $\alpha$ gene in DNA from autonomously functioning thyroid tumors the activating mutation of Arg 201 to His identical to our case was detected $(1,4)$. Moreover, McCune-Albright syndrome, in which the autonomous functioning of multiple endocrine glands occurs, is caused by activating mutations of Gs $\alpha$ coding for substitution of residue Arg 201 to His or Cys in several tissues $(5,6)$. These findings indicate that in our patient somatic mutation of thyroid tissue resulted in the development of an autonomously functioning tumor.

\section{References}

1. Landis AC, Masters SB, Spada A, Pace AM, Bourne HR, Vallar L. GTP ases inhibiting mutations activate the $\alpha$ chain of Gs and stimulate adenylyl cyclase in human pituitary tumors. Nature 1989; 340: 692-6.
2. Spada A, Vallar L, Faglia G. G protein oncogenes in pituitary tumors. Trends Endocrinol Metab 1992; 3: 355-9.

3. Lyons J, Landis CA, Harsh G, Vallar L, Grunewald K, Feichtinger $\mathrm{H}$, et al. Two G protein oncogenes in human endocrine tumors. Science 1990; 249: 655-8.

4. Suarez HG, du Villard JA, Caillou B, Schlimberger M, Parmentier C, Monier R. gsp mutation in human thyroid tumor. Oncogene 1991; 6: 677-9.

5. Weinstein LS, Shenker A, Gejman PV, Merino MJ, Friedman E, Spiegel AM. Activating mutations of the McCune-Albright syndrome. N Engl J Med 1991; 325: 168895.

6. Scwindinger WF, Francomano CA, Leveine MA. Identification of a mutation in the gene encoding the a subunit of the stimulatory $G$ protein of adenylyl cyclase in McCuneAlbright syndrome. Proc Natl Acad Sci USA 1992; 89: 5152-6.

7. Spiegel AM, Shenker A, Weinstein LS. Receptor-effector coupling by G-proteins: Implications for normal and abnormal signal transduction. Endocr Rev 1992; 13: 536-65.

8. O'Sullivan C, Barton CM, Staddon SL, Brown CL, Lemonie NR. Activating point mutations of the gsp oncogene in human thyroid adenoma. Mol Carcinog 1991; 4: 345-8.

9. Saito S. Pathophisiology and gene abnormalities of endocrine tumor. Folia Endocrinol 1992; 68: 1225-39.

10. Burton FH, Hpasel KW, Bloom FE, Sutcliffe JG. Pituitary Hyperplasia and gigantism in mice caused by a chorela toxin transgene. Nature 1991; 350: 566-8. 
December 1995

Somatic Gs $\alpha$ Mutation in Toxic Thyroid Nodule

11. Tajima T, Fujieda K, Fujii-Kuriyama Y. De novo mutation causes clinical discordance between steroid 21-hydroxylase deficiecny with HLA identical siblings. J Clin Endocrinol Metab 1994; 87: 88-9. 